rupture and dissection has been described and was the probable cause of death in five of the 51 cases cited by Cruickshank and Marquis. ${ }^{4}$ It has been assumed that aneurysm of the ductus may resolve spontaneously as thrombus within it becomes organised and fibrosed, but there is no documented evidence for this. In view of the possible fatal complications, therefore, surgical treatment is advocated. Heikkinen and Simila were the first to describe successful elective resection of the aneurysm in two neonates. ${ }^{3}$

Greater awareness of the condition could have facilitated a preoperative diagnosis in case 1 . It was impossible to achieve vascular control at left thoracotomy but the use of cardiopulmonary bypass, hypothermia, and circulatory arrest would certainly have helped in achieving haemostasis. Review of reported work showed only one successfully treated ruptured aneurysm. ${ }^{5}$ We recommend the use of cardiopulmonary bypass in suspected cases of aneurysmal rupture.

Because of our experience with case 1 , the diagnosis was easily made with the use of echocardiography in case 2 . The presence of a cystic mass in continuity with the left pulmonary artery and the aorta was unmistakable. Provided one maintains a high index of suspicion and includes aneurysm of the ductus in the differential of all mediastinal masses, the diagnosis can accurately and confidently be made on echocardiography. Further investigations, particularly angiography (which may jeopardise an already critically ill infant), are unnecessary.

In the second case the early natural history of the condition was documented. The rapid reduction in the size of the aneurysm led us to question the need for surgical intervention in all cases. A conservative policy of closely monitoring the clinical progress and echocardiographic appearances was adopted. If the aneurysm had not undergone rapid resolution or had increased in size we would have resected it because of the risks of endocarditis, ruputure, and compression of adjacent structures.

We recommend urgent operations using cardiopulmonary bypass if a ruptured aneurysm is suspected. If there is no evidence of rupture, however, we believe a conservative policy of monitoring the progress of the aneurysm by echocardiography is justified. If the aneurysm increases in size or does not undergo rapid resolution we recommend urgent resection.

\section{Addendum}

Since submitting this paper we have recognised two further cases. One resolved spontaneously and the other was corrected during cardiac surgery for pulmonary atresia.

\section{References}

1 Heikkinen ES, Simila S, Laitinen J, et al. Infantile aneurysm of the ductus arteriosus: diagnosis, incidence, pathogenesis and prognosis. Acta Paediatr Scand 1974;63:241-8.

2 Kirks DR, McCook TA, Serwer GA, et al. Aneurysm of the ductus arteriosus in the neonate. AJR 1980;134:573-6.

${ }^{3}$ Heikkinen ES, Simila S. Aneurysm of the ductus arteriosus in infancy: report of two surgically treated cases. $J$ Pediatr Surg 1972;7:392-7.

4 Cruickshank B, Marquis RM. Spontaneous aneurysm of the ductus arteriousus: a review and report of the tenth adult case. Am J Med 1958;25:140-9.

5 Ferlic RM, Hofschire PJ, Mooring PK. Ruptured ductus arteriosus aneurysm in an infant - report of a survivor. Ann Thorac Surg 1975;20:456-60.

Correspondence and requests for reprints to $\mathrm{Mr}$ PS Malone, Department of Paediatric Surgery, Hospital for Sick Children, Great Ormond Street, London WC1N 2JH.

Accepted 6 March 1989

\title{
Ciprofloxacin in neonatal Enterobacter cloacae septicaemia
}

\author{
M J BANNON, P R STUTCHFIELD, A M WEINDLING, AND V DAMJANOVIC* \\ Department of Child Health, Liverpool Maternity Hospital, and *Department of Microbiology, Sefton \\ General Hospital, Liverpool
}

SUMMARY Multiresistant Enterobacter cloacae infection in six premature infants was eradicated with intravenous ciprofloxacin $(10 \mathrm{mg} / \mathrm{kg} / \mathrm{day})$. Bacterial resistance did not develop. Adequate plasma ciprofloxacin concentrations were achieved in all treated patients. No clinical evidence of side effects was observed.
Modi et al have documented an outbreak of multiresistant Enterobacter cloacae infection that was observed in this regional intensive care unit between July 1985 and January 1987. ' The organism was resistant not only to penicillins and aminoglycosides but also to third generation cephalosporins. Later in 1987 a further six infants developed septicaemia due to the same multiresistant strain of $E$ cloacae that showed in vitro sensitivity to ciprofloxacin (Ciproxin, 
Baypharm). Ciprofloxacin is a new synthetic fluoroquinolone with broad spectrum bactericidal activity and effective tissue penetration. ${ }^{2}$ It has not been recommended for use in children as it has caused arthropathy in weight bearing joints of experimental animals. Chapman et al had previously treated $E$ cloacae septicaemia with ciprofloxacin in a premature infant. ${ }^{3}$ We report our experience of treating the six infants in the second outbreak of E cloacae infection with ciprofloxacin.

\section{Patients and methods}

\section{CLINICAL ASPECTS}

The six infants were treated in the regional neonatal intensive care unit, Liverpool Maternity Hospital. All infants had received at least two courses of different antibiotics before the ciprofloxacin. These included ampicillin, gentamicin, netilmicin, cefotaxime, and chloramphenicol. Ciprofloxacin 10 $\mathrm{mg} / \mathrm{kg} /$ day in two divided doses was given intravenously for 14 days to infants $2-5$ and 21 days in the case of infant 1 who had ventriculitis. Patient 6 died nine days after ciprofloxacin was started.

Serum concentrations were estimated after the third dose in all cases, and in the cerebrospinal fluid on two occasions in one infant.

\section{SURVEILLANCE AND TREATMENT}

Prevention practices and antibiotic treatment of babies in this nursery have been described previously. ${ }^{1}$ The combination of ampicillin and gentamicin was used as a standard initial treatment of suspected infection.

\section{LABORATORY METHODS}

Isolation and identification of organisms as well as the breakpoint technique for determination of antibiotic sensitivities were used. ${ }^{1}$ The breakpoints for ciprofloxacin were $0.5 \mathrm{mg} / \mathrm{l}$ (low) and $2.0 \mathrm{mg} / 1$ (high). The sensitivity of the strains of $E$ cloacae isolated initially were tested by Stokes disc method ${ }^{1}$ with disc concentration of $5 \mathrm{mg}$. For selected strains, the minimum inhibitory concentration of ciprofloxacin was determined. For this Adatabs (Mast House, Bootle) were used to make twofold dilutions ranging from $2 \mathrm{mg} / \mathrm{l}$ to $0.015 \mathrm{mg} / \mathrm{l}$, a technique similar to the breakpoint method. ${ }^{1}$

Ciprofloxacin serum concentrations were measured by high performance liquid chromatography. Trough and peak plasma concentrations were measured, taking blood 30 minutes after intravenous injection for the latter.

\section{Results}

\section{CLINICAL ASPECTS}

All six infants were premature and of very low birth weight (see table 1). All infants were ventilated for chronic lung disease. Three infants had periventricular haemorrhages and two developed necrotising enterocolitis before the institution of ciprofloxacin treatment. The initial sites of colonisation with $E$ cloacae are shown in table 1 . There was a short interval between colonisation and the onset of systemic infection in the majority. Although $E$ cloacae was eradicated in every case, three of the six infants died. The causes of death were necrotising enterocolitis and bronchopulmonary dysplasia in infant 3 , bronchopulmonary dysplasia in infant 4 , and necrotising enterocolitis in infant 6 . In all infants $E$ cloacae had been eradicated four to five days after starting ciprofloxacin.

Table 1 Patient details

\begin{tabular}{|c|c|c|c|c|c|}
\hline $\begin{array}{l}\text { Patient } \\
\text { No }\end{array}$ & $\begin{array}{l}\text { Gestation } \\
\text { (weeks) }\end{array}$ & $\begin{array}{l}\text { Birth } \\
\text { weight }(g)\end{array}$ & $\begin{array}{l}\text { Site of } \\
\text { isolation of } \\
\text { E cloacae }\end{array}$ & $\begin{array}{l}\text { Age at time } \\
\text { of isolation } \\
\text { (days) }\end{array}$ & $\begin{array}{l}\text { Outcome and } \\
\text { cause of death }\end{array}$ \\
\hline 1 & 28 & 1200 & $\begin{array}{l}\text { Pharyngeal aspirate } \\
\text { Blood } \\
\text { Cerebrospinal fluid }\end{array}$ & $\begin{array}{l}16 \\
24 \\
26\end{array}$ & Survived \\
\hline 2 & 28 & 800 & $\begin{array}{l}\text { Throat swab } \\
\text { Blood }\end{array}$ & $\begin{array}{l}29 \\
29\end{array}$ & Survived \\
\hline 3 & 24 & 800 & $\begin{array}{l}\text { Throat swab } \\
\text { Blood }\end{array}$ & $\begin{array}{l}25 \\
30\end{array}$ & $\begin{array}{l}\text { Died aged } 81 \text { days of } \\
\text { necrotising enterocolitis and } \\
\text { bronchopulmonary dysplasia }\end{array}$ \\
\hline 4 & 26 & 900 & $\begin{array}{l}\text { Pharyngeal aspirate } \\
\text { Blood }\end{array}$ & $\begin{array}{l}6 \\
6\end{array}$ & $\begin{array}{l}\text { Died aged } 66 \text { days of } \\
\text { bronchopulmonary dysplasia }\end{array}$ \\
\hline 5 & 26 & 1000 & $\begin{array}{l}\text { Pharyngeal aspirate } \\
\text { Blood }\end{array}$ & $\begin{array}{l}5 \\
5\end{array}$ & Survived \\
\hline 6 & 29 & 700 & $\begin{array}{l}\text { Throat swab } \\
\text { Blood }\end{array}$ & $\begin{array}{l}6 \\
7\end{array}$ & $\begin{array}{l}\text { Died aged } 19 \text { days of } \\
\text { necrotising enterocolitis }\end{array}$ \\
\hline
\end{tabular}


Table 2 Ciprofloxacin treatment

\begin{tabular}{|c|c|c|c|c|}
\hline \multirow[t]{2}{*}{ Patient No } & \multirow{2}{*}{$\begin{array}{l}\text { Age at } \\
\text { start of } \\
\text { ciprofloxacin (days) }\end{array}$} & \multicolumn{2}{|c|}{ Ciprofloxacin concentration $(\mathrm{mg} / \mathrm{l})$} & \multirow{2}{*}{$\begin{array}{l}\text { Time for eradication } \\
\text { of } E \text { cloacae at } \\
\text { all sites with } \\
\text { ciprofloxacin (days) }\end{array}$} \\
\hline & & Plasma & Cerebrospinal fluid & \\
\hline & & 3rd dose & & \\
\hline \multirow[t]{8}{*}{1} & 35 & Pre 0.04 & $0 \cdot 88$ & \\
\hline & & Post 1.45 & & \\
\hline & & Pre 0.57 & & 4 \\
\hline & & Post $1 \cdot 77$ & & \\
\hline & & 14th dose & & \\
\hline & & Pre 0.52 & 1.45 & \\
\hline & & Post $2 \cdot 15$ & & \\
\hline & & 3rd dose & & \\
\hline \multirow[t]{2}{*}{2} & 42 & Pre 1.0 & & 2 \\
\hline & & Post $3 \cdot 1$ & & \\
\hline \multirow[t]{3}{*}{3} & 49 & Pre $2 \cdot 2$ & & 5 \\
\hline & & Post 4.6 & & \\
\hline & & 3rd dose & & \\
\hline \multirow[t]{3}{*}{4} & 9 & Pre 0.6 & & 4 \\
\hline & & Post $3 \cdot 3$ & & \\
\hline & & 3rd dose & & \\
\hline \multirow[t]{3}{*}{5} & 21 & Pre 2.6 & & 5 \\
\hline & & Post $5 \cdot 7$ & & \\
\hline & & 3rd dose & & \\
\hline \multirow[t]{2}{*}{6} & 10 & Pre $1 \cdot 1$ & & 4 \\
\hline & & Post 2.9 & & \\
\hline
\end{tabular}

MICROBIOLOGICAL ASPECTS

Ciprofloxacin concentrations in serum and cerebrospinal fluid are shown in table 2. The mean concentration in the cerebrospinal fluid was $64 \%$ of the corresponding post dose concentration in the serum.

At the beginning of this outbreak two babies were colonised and infected with strains sensitive to cefotaxime and ceftazidime. Later, isolates from various sites became resistant to these antibiotics. The isolates of $E$ cloacae that subsequently colonised and infected other babies were resistant to cefotaxime and ceftazidime. The biotypes of all these $E$ cloacae isolates were identical-that is, resistant to ampicillin, augmentin, trimethoprim, and cefuroxime. They had reduced sensitivities to aminoglycosides as shown by high breakpoints to gentamicin $(4 \mathrm{mg} / \mathrm{l})$, netilmicin $(4 \mathrm{mg} / \mathrm{l})$, and amikacin $(16 \mathrm{mg} / \mathrm{l})$. All isolates of $E$ cloacae tested both by the disc and breakpoint method were sensitive to ciprofloxacin. The minimum inhibitory concentration for ciprofloxacin was $0.03 \mathrm{mg} / \mathrm{l}$ in four infants and $0.06 \mathrm{mg} / \mathrm{l}$ in two infants. There was no change in minimum inhibitory concentration during treatment with ciprofloxacin.

$E$ cloacae was eradicated from all infants treated with ciprofloxacin. The median time for eradication was four days with a range of two to five days. After the use of ciprofloxacin, $E$ cloacae has not beetro isolated again from infants at this hospital.

\section{Discussion}

As in previously reported outbreaks of $E$ cloacae infection, ${ }^{1}$ the strains causing neonatal infections were multiresistant. In this new outbreak the isolates of $E$ cloacae were initially sensitive to third generation cephalosporins. Subsequent isolates, however, became resistant to cephalosporins, confirming our previous findings and supporting the possibility of a spread of a derepressed mutant. ${ }^{1}$ These resistant strains of $E$ cloacae were eradicated with ciprofloxacin treatment, previous courses of other antibiotics having failed. Resistance to ciprofloxacin was not encountered in our series, although Scully et al have described the development of resistance to ciprofloxacin in pseudomonas infection. $^{4}$

By acting directly on the DNA gyrase enzyme that is present in many Gram negative bacteria, cell division is inhibited and plasmid mediated resistance is thus prevented. ${ }^{2}$ Resistance to ciprofloxacin can only develop by bacterial mutation.

Eradication of the organism was achieved with a mean post dose concentration of $3 \cdot 1 \mathrm{mg} / \mathrm{l}$. We aimed for post dose concentrations below $7.0 \mathrm{mg} / \mathrm{l}$. 
Ciprofloxacin penetrates tissues well and therapeutic concentrations in the cerebrospinal fluid have been achieved even in subjects without inflammation of the meninges. ${ }^{5}$ Isaacs $e t$ al have already reported the successful treatment of ventriculitis caused by a multiresistant Pseudomonas aeruginosa strain. ${ }^{6}$ Concentrations of ciprofloxacin in the cerebrospinal fluid have been reported to be $40 \%$ of concentrations in serum in meningitis. ${ }^{5}$ In our patients $60-70 \%$ of peak plasma concentrations were achieved in the cerebrospinal fluid-14 times the minimum inhibitory concentration of the organism. The ventriculitis was effectively treated with intravenous ciprofloxacin.

Unwanted effects of ciprofloxacin include damage to weight bearing joints, hepatic and renal impairment, interaction with DNA of lymphocytes and with theophylline. No side effects were observed in our patients.

The high mortality in this series was disappointing, although the delay between eradication of the organism and death suggested that death was not directly related to $E$ cloacae infection. Despite the relatively late introduction of ciprofloxacin during the course of the infection the organism was eradicated in all cases.

With the benefit of this experience we would now use ciprofloxacin at a much earlier stage of the infective process, but only when our usual first line antibiotics are ineffective. We would advise caution when considering its use, however, and suggest that it should be prescribed only in instances of proved infection with multiresistant organisms.

We thank Mr R Whitaker for organising and supervising sensitivity testing to ciprofloxacin and Mrs S Longworth for typing this paper.

\section{References}

${ }^{1}$ Modi N, Damjanovic V, Cooke RWI. Outbreak of cepahlosporin resistant Enterobacter cloacae infection in a neonatal intensive care unit. Arch Dis Child 1987;62:148-51.

${ }^{2}$ Ciprofloxacin-an important new antimicrobial. Drug Ther Bull 1987;25:69-72.

${ }^{3}$ Chapman ST, Speller DCE, Reeves DS. Resistance to ciprofloxacin. Lancet 1985;ii:39.

4 Scully BE, Neu HC, Parry MF, Mandell W. Oral ciprofloxacin therapy of infections due to Pseudomonas aeruginosa. Lancet 1986; i:819-22.

5 McLain JB, Rhoads J, Kroll G. Cerebrospinal fluid concentrations of ciprofloxacin in subjects with uninflamed meninges. $J$ Antimicrob Chemother 1988;21:808-9.

${ }^{6}$ Isaacs D, Slack MPE, Wilkinson AR, Westwood AW. Successful treatment of Pseudomonas ventriculitis with ciprofloxacin. $J$ Antimicrob Chemother 1986;17:535-8.

Correspondence to $\operatorname{Dr}$ A M Weindling, Regional Neonatal Intensive Care Unit, Liverpool Maternity Hospital, Oxford Street, Liverpool L7 7BN.

Accepted 11 April 1989

\title{
Fetal ascites: an unusual presentation of Niemann-Pick disease type $\mathrm{C}$
}

\author{
I K MACONOCHIE, ${ }^{*} \mathrm{~S}$ CHONG,${ }^{*}$ G MIELI-VERGANI, ${ }^{*}$ B D LAKE, $\dagger$ AND A P MOWAT* \\ ${ }^{*}$ Department of Child Health, King's College Hospital, and †Department of Histopathology, Institute of \\ Child Health, London
}

\begin{abstract}
SUMmaRY Two infants were seen with severe ascites detected before birth, a previously unreported presentation of Niemann-Pick disease type C. In the second infant no diagnostic storage cells were present in bone marrow. Confirmatory investigations were prompted by experience of the first case.
\end{abstract}

Niemann-Pick disease type $\mathrm{C}$ is a heterogeneous neurovisceral storage disorder inherited in an autosomal recessive fashion. A defect in cholesterol esterification has been identified, so that antenatal diagnosis is possible. ${ }^{1}$
Three presentations have been described. Some patients present with jaundice and hepatosplenomegaly in the first two months of life, most of whom become symptom free, though a few die of liver failure by the age of 6 months. Others have asymptomatic splenomegaly in the first six years of life, and yet others develop progressive neurological dysfunction or psychosis, with or without splenomegaly, between the ages of 2 and 59 years.

Progressive neurological deterioration occurs in all cases, often causing death by the third decade. Diagnosis is suspected on identifying typical storage cells in bone marrow and confirmed by electron microscopy of neural tissue; in addition a laboratory test has recently been described. ${ }^{1}$ 